\title{
STUDIES IN PHOSPHORUS METABOLISM IN MAN. III. THE DISTRIBUTION, EXCHANGE AND EXCRETION OF PHOSPHORUS IN MAN USING RADIOACTIVE PHOSPHORUS (P') AS A TRACER ${ }^{1}$
}

\author{
By STANLEY M. LEVENSON,2, 3, 4 MARGARET A. ADAMS, ${ }^{3}$ HYMAN ROSEN,2 AND \\ F. H. LASKEY TAYLOR ${ }^{3}$ \\ (From the U. S. Army Medical Nutrition Laboratory 9937 TSU-SGO, 1849 West Pershing \\ Road, Chicago 9, Ill.)
}

(Submitted for publication August 25, 1952; accepted March 4, 1953)

\section{INTRODUCTION}

In the course of some metabolic studies in man, it became important to know in some detail the fate of injected radiophosphorus. Although $\mathrm{P}^{32}$ has been used extensively as a tracer in animal metabolic studies, its use in man has been largely limited to the therapy of various hematologic and malignant disorders, and to the determination of circulating red cell volume. Accordingly, we have followed the distribution of radiophosphorus in various plasma, red cell, and urine fractions, after the intravenous administration of 100 to $200 \mathrm{mi}$ crocuries of $\mathrm{P}^{\mathbf{3 2}}$, as inorganic phosphate, into normal men. The effects of glucose and insulin on phosphorus partition were also observed. These data form the basis for a discussion of the kinetics of phosphorus transfer and distribution.

\section{METHODS}

Healthy young adult males served as subjects. They weighed, on the average, about $75 \mathrm{Kg}$. and were on normal food intakes prior to study. Observations were made after a 12 hour fast. Radioactive phosphorus (100 to $200 \mu \mathrm{C} \mathrm{P}^{\mathrm{m}}$ ), in the form of $\mathrm{Na}_{2} \mathrm{HP}^{2} \mathrm{O}_{4}$ (carrier-free) dissolved in about $3 \mathrm{ml}$. of pyrogen-free water, was injected intravenously in a few seconds into an antecubital vein. Blood samples were thereafter collected serially from the opposite arm. The blood was collected in bottles containing dried potassium-ammonium oxalate ad-

1 This work was aided in part, by gifts from Smith, Kline and French Laboratories, Philadelphia, and the American Cancer Society (Massachusetts Division), to Harvard University.

2 Army Medical Service Graduate School, Walter Reed Army Medical Center, Washington 12, D. C.

8 Thorndike Memorial Laboratory, 2nd and 4th Medical Services (Harvard), Boston City Hospital, Boston, Massachusetts.

- Surgical Service of the Medical College of Virginia, Richmond, Virginia.

- $\mathrm{P}^{\mathrm{w}}$ was supplied by Monsanto Chemical Co., Clinton Laboratories, Oak Ridge, Tennessee. justed to produce no change in red cell size. The blood samples, cooled in ice, were centrifuged for 10 minutes at 2,000 rpm as soon as possible, and the plasma removed. The red cells were washed once with ice cold isotonic sodium chloride solution, centrifuged again, and the supernatant washings removed as completely as possible and discarded. The washed red blood cells were rapidly frozen at $-20^{\circ} \mathrm{C}$. to minimize hydrolysis of phosphorus compounds and to produce hemolysis. Plasma and hemolyzed red blood corpuscles were each analyzed chemically for total phosphorus, total acid soluble phosphorus, and inorganic phosphorus by the methods of Fiske and Subbarow (1). The radioactivity of these phosphate fractions was determined according to methods previously described (2). Values for the trichloroacetic acid soluble organic and the trichloroacetic acid insoluble fractions were calculated. In some subjects, the effects of intravenous glucose $(25 \mathrm{gm}$.), or crystalline insulin (0.1 unit per $\mathrm{Kg}$. body weight) were observed. Urine samples were also collected serially and total $\mathrm{P}^{\mathrm{n}}$ and phosphorus measured.

\section{RESULTS}

\section{Disappearance of $P^{82}$ from plasma}

The course of the disappearance of $\mathrm{P}^{32}$ from the plasma, following the single rapid intravenous injection of labeled phosphate, is shown in Figure 1. The experimental points have been plotted semi-logarithmically and represent observations made on seven normal young adult males.

The data suggest a very rapid transcapillary migration of $\mathrm{P}^{32}$. This is evident from the following calculation: if the mixing phase of $\mathrm{P}^{32}$ in the plasma is over, and the uptake of $\mathrm{P}^{32}$ by the blood cells is minimal in the first few minutes $(3,4$, vide infra) the dilution of $\mathrm{P}^{32}$ at the end of this time would represent the plasma volume were the $P^{32}$ wholly contained in the vascular tree. It can be seen from Figure 1 that after the first few minutes only some 1 per cent of the total injected $\mathrm{P}^{82}$ is found in each $100 \mathrm{ml}$. plasma. This leads to a calculated plasma volume of some 10 


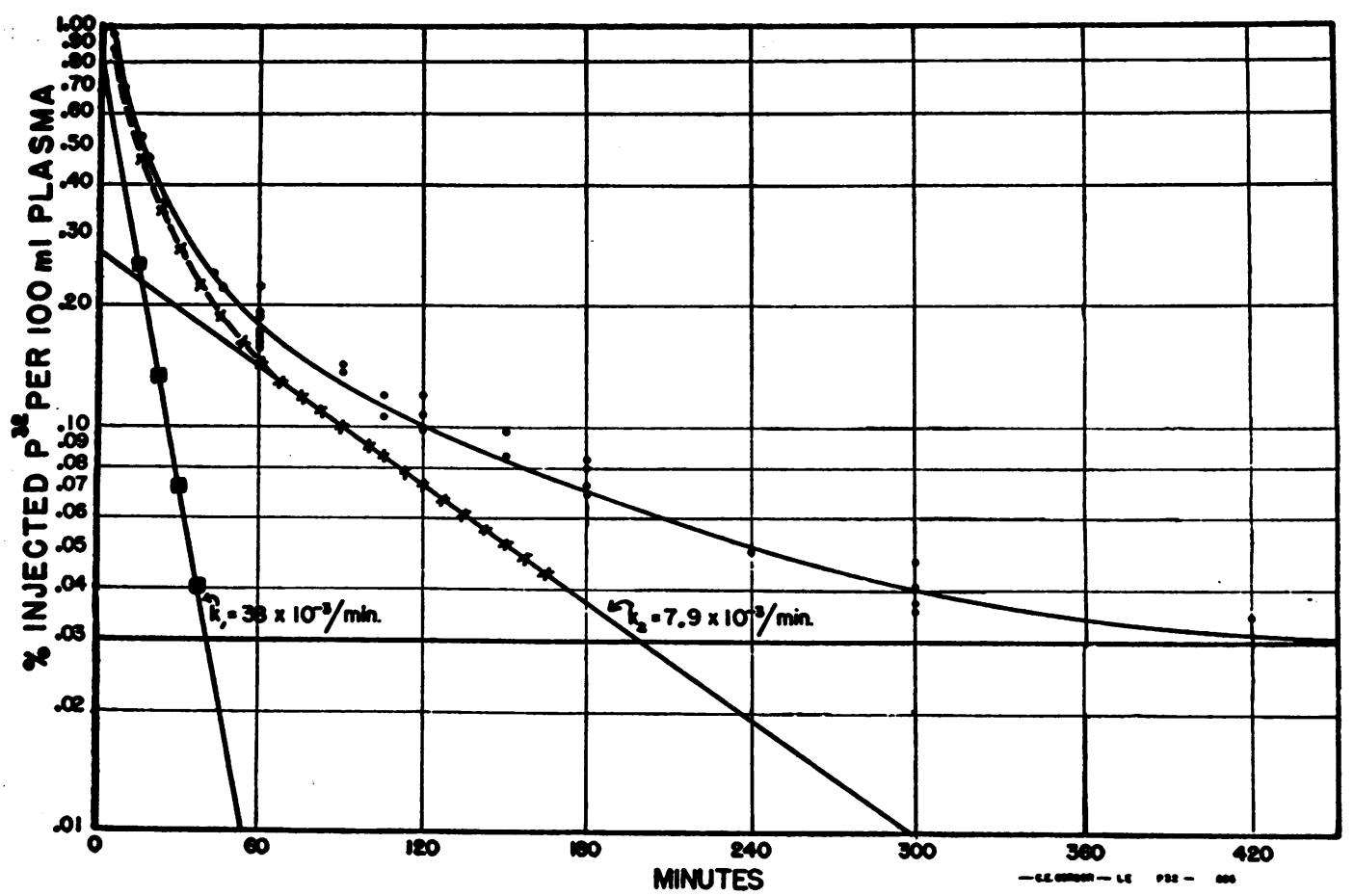

Fig. 1.

\footnotetext{
$\longrightarrow$ Semi-logarithmic plot of the course of disappearance of $\mathrm{P}^{\mathrm{sz}}$ from plasma.

These data are derived from the experimental curve, and illustrate its double exponential nature.
}

litres. This figure is much too high for plasma volume, but only slightly lower than an expected value (12 litres) for total extracellular fluid (5), and suggests a very rapid transcapillary migration of radiophosphorus. A true value for extracellular space is not to be expected from this calculation, since it would necessitate homogeneous distribution of the radiophosphorus in the interstial fluid and limitation of the radiophosphorus to this space. Pappenheimer, Renkin, and Borrero (6) have shown that there is an arterio-venous difference in the concentrations of various injected ions and that a homogeneous plasma ion pool can only be approximated. Because of the access of phosphate to intracellular pools, it is unlikely to be uniformly mixed in the extravascular fluid after its escape from the capillaries.

An apparent rapid transcapillary movement of $\mathrm{P}^{\mathbf{s 2}}$ was also observed by Kleiber, Smith, and Ralston in cows (7). Walker and Wilde (8) similarly found that 90 per cent of injected $K^{\mathbf{4 2}}$ moves out of the plasma of rabbits within one minute following its intra-arterial injection.

Following the initial very rapid decrease in plasma radioactivity in the first few minutes after the injection of labeled phosphate, its disappearance slows. A smooth curve drawn through the experimental points plotted semilogarithmically (Figure 1) fits the exponential type equation

$\mathrm{P}=\mathrm{a}_{1} \mathrm{e}^{-\mathrm{b}_{1} t}+\mathrm{a}_{2} \mathrm{e}^{-\mathrm{b}_{2} t} \cdots+\mathrm{a}_{\mathrm{n}} \mathrm{e}^{-\mathrm{b}_{n} t}+\mathrm{P}_{\mathrm{eq}}$.

In the equation, $P=$ per cent injected $P^{32}$ found in each $100 \mathrm{ml}$. plasma at time $t$ after injection, $\mathrm{P}_{\mathrm{eq}}$ represents the "steady state" level expressed in the same units, and $a_{1}, a_{2}, a_{n}$ and $b_{1}, b_{2}$, $b_{n}$ are constants.

By the seventh hour after the injection of the labeled phosphate the rate of its disappearance from the plasma has become very slow. As a first approximation, it is assumed that a steady state has been reached. In Figure 1 the straight line drawn from this point and extrapolated back to zero time represents $P_{\text {eq. }}$. When this "equilibrium" line is subtracted graphically from the experimentally obtained curve, another curve is obtained. The process of extrapolation and subtraction is repeated with this curve, and a last, steep straight line is the result. 
The three straight lines can be formally considered to represent three processes, in which a is the $y$ intercept of each line, and $b$ is the slope. The equation now becomes

$$
\mathrm{P}=0.85 \mathrm{e}^{-0.08 t}+0.27 \mathrm{e}^{-0.01 \mathrm{t}}+0.03 \text {. }
$$

One other formal mathematical manipulation can be applied to the derived equation. This is the assignment of "transfer coefficients" to the two processes represented on the graph by the two steep straight lines, and in the equation by the first two terms. This is a formal step, and does not imply that the processes are separate or real, or that they are taking place in homogeneous "pools."

According to Solomon (9), the transfer coefficients of the processes represented by the semilogarithmic plots can be evaluated with a degree of accuracy depending on the validity of the following assumptions :

1) The various body compartments maintain a constant size during the period of study ;

2) The transfer coefficients across membranes are the same in both directions;

3) The total injected $P^{32}$ is maintained within the body compartments under study, i.e., no excretion. It is clear that this assumption is to some extent unwarranted, since it was found that in the first seven hours after injection, 5 to 10 per cent of the injected $\mathrm{P}^{32}$ was excreted (Figure 5 ). Neglecting this error, the slopes $\left(b_{1}\right.$ and $\left.b_{2}\right)$ bear the following relationships to the transfer coefficients $\left(\mathrm{k}_{1}\right.$ and $\left.\mathrm{k}_{2}\right)$ :

$$
\begin{aligned}
& b_{1}=\left(k_{1}+k_{2}\right)+\sqrt{k_{1}{ }^{2}-k_{1} k_{2}+k_{2}^{2}}, \\
& b_{2}=\left(k_{1}+k_{2}\right)-\sqrt{k_{1}{ }^{2}-k_{1} k_{2}+k_{2}^{2}} .
\end{aligned}
$$

Solving these equations simultaneously,

$$
\begin{aligned}
& \mathrm{k}_{1}=38 \times 10^{-3} \text { per min., } \mathrm{t} \frac{1}{2}=18 \mathrm{~min} . \\
& \mathrm{k}_{2}=7.9 \times 10^{-3} \text { per min., } \mathrm{t} \frac{1}{2}=87 \mathrm{~min} .
\end{aligned}
$$

It will be seen that $k_{1}$ and $k_{2}$ have the units of time $^{-1}$. They are, therefore, in a mathematical sense true rate constants, and signify that the labeled phosphate is disappearing in one process at the rate of 3.8 per cent per minute, and in the other process at 0.79 per cent per minute based on the amounts still present at time $t$.

What these processes represent physiologically is not certain. They may represent intracellular transfer. The double exponential nature of this phase of the disappearance suggests that phosphate enters one group of cells rapidly and another group relatively slowly. More precise characterization of these transfers depends on specific cellular analyses.

\section{Appearance of $P^{32}$ in the red cells}

The in vivo uptake of $\mathrm{P}^{32}$ by red cells is shown graphically in Figure 2. This curve can be represented by

$$
Q=a_{1}\left(1-e^{-b_{1} t}\right)+a_{2}\left(1-e^{-b_{2} t}\right) .
$$

When $Q=$ per cent injected $P^{32}$ per $100 \mathrm{ml}$. red cells,

$$
\mathrm{Q}=0.07\left(1-\mathrm{e}^{-.30 t}\right)+0.13\left(1-\mathrm{e}^{-.02 t}\right) \text {. }
$$

The first term is significant during only the first 10 to 20 minutes. The concentration of $\mathrm{P}^{32}$ in the red cell increases sharply during this time and then rather abruptly levels off. The rapid leveling off is probably due to the simultaneous es-

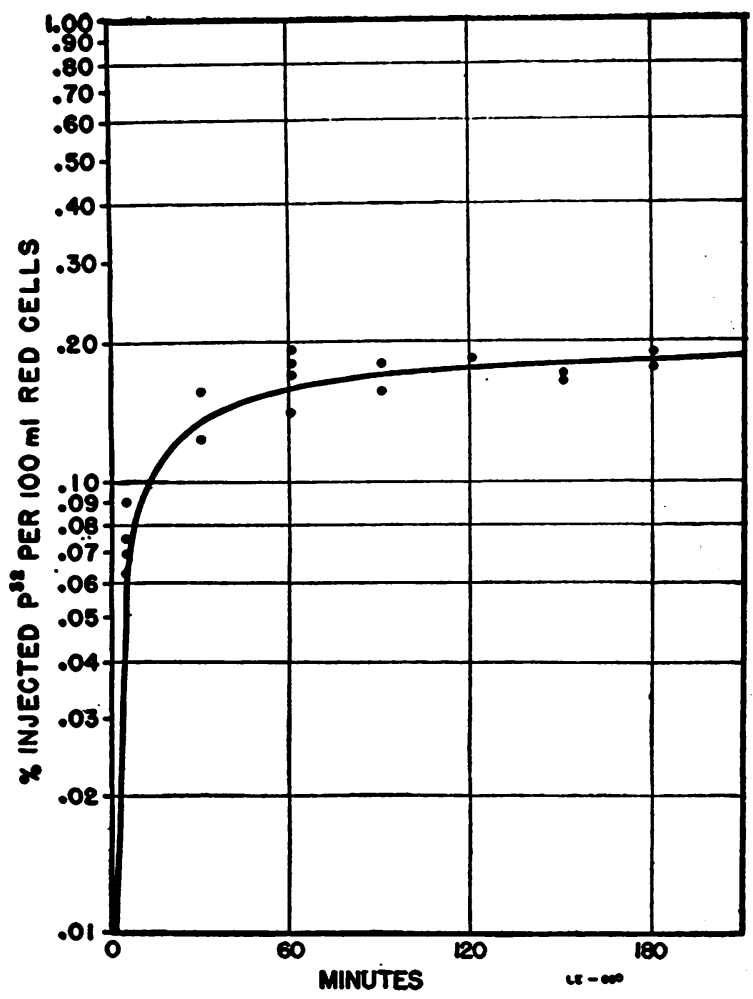

Fig. 2. Semi-logarithmic Plot of $\mathrm{P}^{22}$ Uptake by Rep Cells in Vivo

The curve is a composite of data on four subjects. 


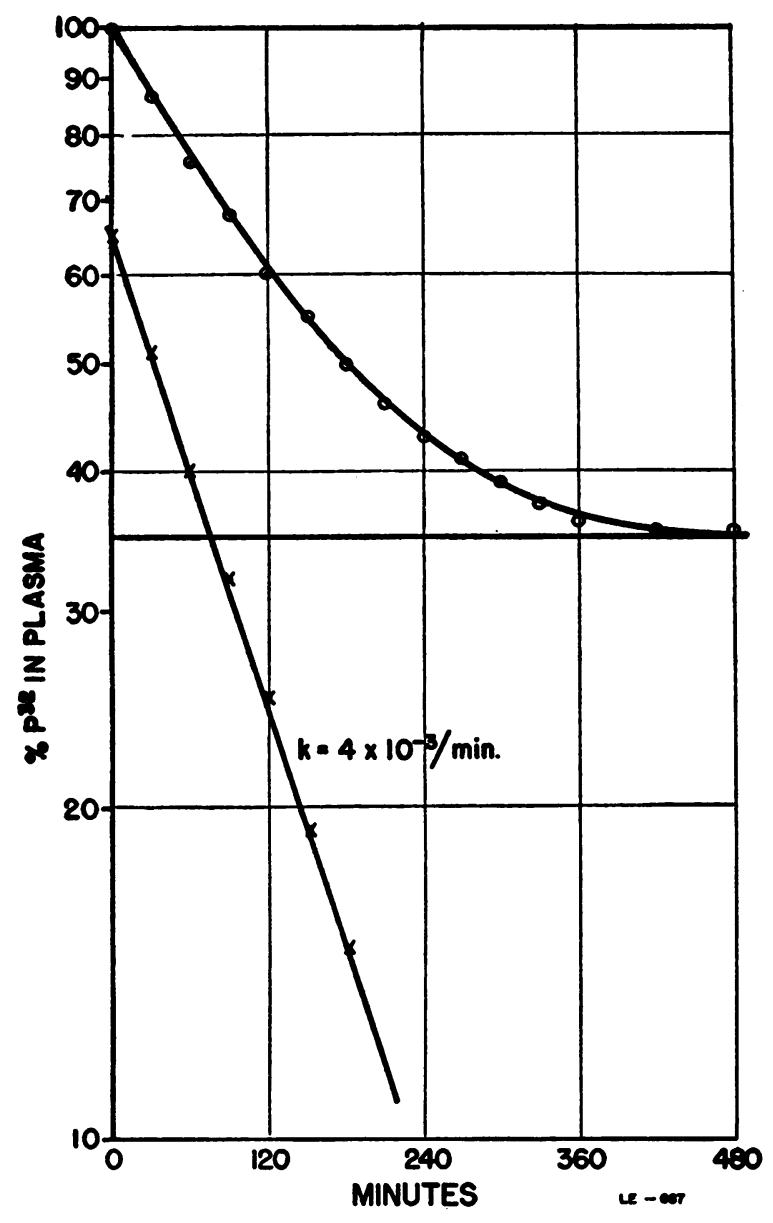

Fic. 3. Graphical Derivation of the Transfer Coefficient of $\mathrm{P}^{2 z}$ from Plasma to Red Cells, at $37^{\circ} \mathrm{C}$. IN VITRO

cape of $\mathrm{P}^{32}$ from the plasma into other body compartments. Experiments, done by ourselves and others, on the uptake of $\mathrm{P}^{32}$ by red cells in vitro (8), indicate that the uptake from plasma by red cells is relatively slow. During the first two hours the measured disappearance of $\mathrm{P}^{32}$ from the plasma in vitro occurs exponentially. From our in vitro data (Figure 3 ), we have calculated a transfer coefficient of 0.4 per cent per min. at $37^{\circ} \mathrm{C}$.

\section{Effect of insulin and glucose on plasma radio- phosphate disappearance}

The effect of insulin and glucose on the movement of $\mathrm{P}^{32}$ was studied in a few subjects. Crystalline insulin ( 0.1 unit per $\mathrm{Kg}$. I.V.), or glucose (25 gm. I.V.) was administered one hour after injection of $\mathrm{P}^{32}$. In each case, an accelerated movement of $\mathrm{P}^{32}$ out of the plasma was observed (Figure 4). In the case of glucose, this movement was approximately three times normal, while insulin gave rise to a rate four times normal. In all cases, the eventual equilibrium level of $\mathrm{P}^{32}$ found in the plasma was about 0.03 per cent $P^{32}$ injected per $100 \mathrm{ml}$. plasma.

No information regarding the effect of glucose or insulin on the rate of entry of $\mathrm{P}^{32}$ into the red cell was obtained in our in vivo studies since the net uptake was practically over at the time of glucose and insulin administration.

\section{Urinary excretion of injected $P^{32}$}

The cumulative values of per cent injected $P^{32}$ excreted in the urine are shown in Figure 5 and Table I. These curves were found empirically to be represented by the equation

$$
\mathrm{R}=\mathrm{R}_{0} \mathrm{a}\left(1-\mathrm{e}^{-\mathrm{bt}}\right),
$$

where $R=$ per cent injected $P^{32}$ found in urine after $t$ minutes, and $a$ and $b$ are constants. Since the first urine collections were made one hour after $\mathrm{P}^{32}$ injection, the single term of this equation applies only to later data. A rearrangement of equation 7 gives

$$
\ln \left(1-\frac{R}{R_{0} a}\right)=-b t .
$$

A plot of $\ln \left(1-\frac{R}{R_{0} a}\right)$ against $t$ should yield a straight line, the slope of which is $-b$ (Figure 6), representing the rate of passage of $\mathrm{P}^{32}$ into urine. Failure of this function to pass through the value 1.0 at zero time probably reflects the effect of another term in equation 7 which we have neglected, as mentioned. The average rate of urinary $\mathrm{P}^{32}$ excretion obtained in this way is $7.8 \times 10^{-3} \mathrm{per}$ min. (Table II), a figure identical to that of rate constant $k_{2}$ derived from the plasma radiophosphate determinations. The effects of a single intravenous injection of glucose or insulin were not reflected in the urine phosphorus.

\section{Body phosphorus pool}

We have calculated the size of a body "phosphorus pool," and its turnover rate, using the methods which Sprinson and Rittenberg developed for calculation of the body "nitrogen pool" (10). 

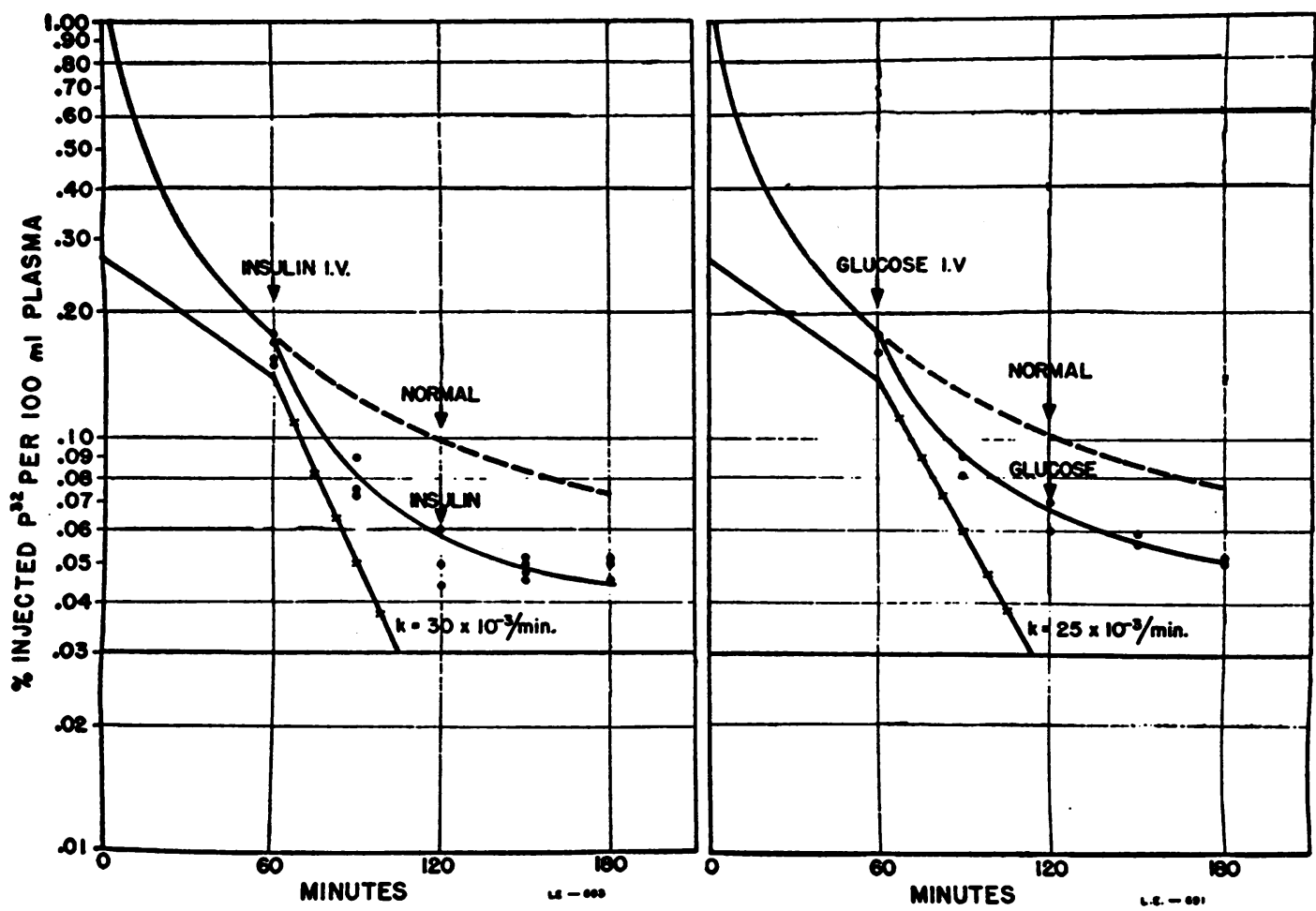

Fig. 4. Effect of Intravenous Glucose and Insulin on the Rate of Disappearance of $\mathrm{P}^{22}$ From Plasma

The body "phosphorus pool" with which we are concerned is the rapidly exchangeable phosphorus. Sprinson and Rittenberg showed theoretically,

$$
a=\frac{E}{E+S} \text { and } b=\frac{E+S}{P} \text {, }
$$

where $a$ and $b$ are the constants of equations 7 and 8 above, $\mathrm{E}=\mathrm{mg}$. nitrogen excreted per min., $\mathrm{S}=$ rate of turnover of body pool nitrogen in $\mathrm{mg}$. per min., and $\mathrm{P}=$ size of the nitrogen body pool in $\mathrm{mg}$.

We have assumed these same relationships for phosphorus. The results of our calculations are listed in Table II. The average size of the rapidly exchangeable phosphorous body pool $(\mathrm{P})$ is about $1,200 \mathrm{mg}$. in our subjects. These subjects, as mentioned, were young adult males in good health, weighing on the average about $75 \mathrm{Kg}$., and were on normal food intakes prior to study. The observations were made after a 12 hour fast. The total phosphorus in such an individual is about 150 gm. (11). Thus, under the conditions of this study, the rapidly exchangeable phosphorus amounts to about 0.2 per cent of the total body phosphorus. Kleiber, Smith, and Ralston (7), calculated the exchangeable body phosphorus for cows to be about 0.5 to 0.9 per cent of the total body phosphorus. The average rate $(\mathrm{S})$ at which phosphorus leaves the rapidly exchangeable body phosphorus pool in our subjects is about $8.5 \mathrm{mg}$. per min. or about 0.7 per cent of the pool per min., a figure similar to the rate at which $\mathrm{P}^{32}$ enters the urine ( 0.8 per cent injected $\mathrm{P}^{32}$ per min.) and the rate of disappearance of $\mathrm{P}^{32}$ from plasma represented by $k_{2}$ ( 0.8 per cent per min.). Thus, the rapidly exchangeable body phosphorous pool turns over approximately ten times per day under the conditions of this study.

\section{Distribution of injected $\mathrm{P}^{32}$ in various plasma phosphorus fractions}

Tables III, IV, and V present detailed data on distribution of $\mathrm{P}^{32}$ in various plasma phosphorous fractions of control subjects, those receiving glucose, and those receiving insulin, respectively. Control data are available as serial observations in two subjects over a four hour period, and in six 


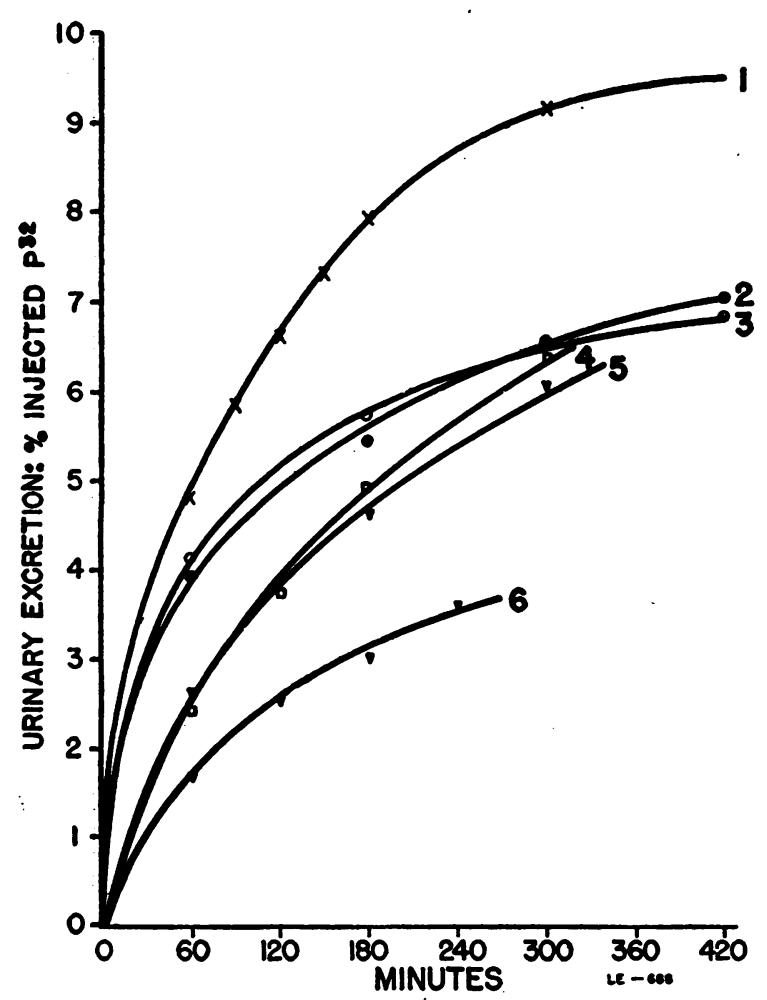

Fig. 5. Cumulative Urinary Pe Excretion of Six Normal Males

subjects at one hour after injection. Variations in some of the chemically measured fractions in the plasma and red cells, somewhat greater than expected from possible technical error, were observed in some of the control subjects. During the period of time under consideration, most of the injected $\mathrm{P}^{32}$ remained in the inorganic fraction. The percentage of $\mathrm{P}^{32}$ in the organic phosphorus fractions varied from 0 to 12 per cent, with a mean of 6 per cent. This average percentage is just outside the error of the methods of measurement. Essentially all of the $\mathrm{P}^{\mathrm{s} 2}$ which had gone into the organic fractions was in the acid insoluble phase. These in vivo data demonstrate substantially the same findings as the results obtained previously in in vitro studies at $37^{\circ} \mathrm{C}$. (12).

Regarding the organic fractions, there does not appear to be any progressive shift of $\mathrm{P}^{32}$ to the very small acid soluble organic component. This raises the question of whether there actually exists, in human plasma, an acid soluble organic fraction, since one would expect that during a period of four hours, there would be a measurable
TABLE I

Urinary excretion of $P$ following the intravenous administration of $P^{22}$ labeled phosphate

\begin{tabular}{|c|c|c|c|c|}
\hline $\begin{array}{c}\text { Time } \\
\text { after } \\
\text { injection } \\
\text { hrs. }\end{array}$ & Subject & $\begin{array}{c}\text { Total P } \\
\text { excreted } \\
\text { (cumulative) } \\
\text { mg. }\end{array}$ & $\begin{array}{c}\text { Per cent } \\
\text { injected P*a } \\
\text { excreted } \\
\text { (cumulative) }\end{array}$ & $\begin{array}{l}\text { Specific } \\
\text { activity* }\end{array}$ \\
\hline 1 & $\begin{array}{r}1 \\
2 \\
3 \\
5 \\
6 \\
7 \\
8 \\
9 \\
10 \\
11 \\
13 \\
14 \\
15 \\
16\end{array}$ & $\begin{array}{r}83 \\
4 \\
115 \\
23 \\
86 \\
59 \\
39 \\
160 \\
54 \\
120 \\
88 \\
16 \\
280 \\
110\end{array}$ & $\begin{array}{l}2.5 \\
2.9 \\
1.6 \\
3.9 \\
4.2 \\
2.6 \\
2.4 \\
4.8 \\
4.7 \\
6.4 \\
3.1 \\
1.8 \\
1.6 \\
3.1\end{array}$ & $\begin{array}{l}0.030 \\
0.725 \\
0.014 \\
0.170 \\
0.049 \\
0.044 \\
0.062 \\
0.030 \\
0.087 \\
0.054 \\
0.038 \\
0.110 \\
0.006 \\
0.028\end{array}$ \\
\hline 2 & $\begin{array}{r}2 \\
3 \\
8 \\
9 \\
10 \\
11 \\
13 \\
14 \\
15 \\
16\end{array}$ & $\begin{array}{r}12 \\
205 \\
71 \\
200 \\
94 \\
165 \\
105 \\
35 \\
290 \\
120\end{array}$ & $\begin{array}{l}3.2 \\
2.5 \\
3.7 \\
6.6 \\
6.5 \\
9.2 \\
4.0 \\
2.8 \\
1.9 \\
3.6\end{array}$ & $\begin{array}{l}0.267 \\
0.012 \\
0.052 \\
0.033 \\
0.069 \\
0.056 \\
0.038 \\
0.080 \\
0.007 \\
0.030\end{array}$ \\
\hline 3 & $\begin{array}{r}2 \\
3 \\
5 \\
6 \\
7 \\
8 \\
9 \\
10 \\
11 \\
13 \\
14 \\
15 \\
16\end{array}$ & $\begin{array}{r}27 \\
250 \\
55 \\
135 \\
115 \\
115 \\
255 \\
115 \\
190 \\
125 \\
55 \\
300 \\
125\end{array}$ & $\begin{array}{r}3.7 \\
2.9 \\
5.2 \\
5.8 \\
4.6 \\
4.9 \\
7.8 \\
7.1 \\
10.0 \\
4.4 \\
4.3 \\
2.2 \\
3.7\end{array}$ & $\begin{array}{l}0.140 \\
0.012 \\
0.095 \\
0.042 \\
0.040 \\
0.043 \\
0.030 \\
0.060 \\
0.052 \\
0.035 \\
0.078 \\
0.007 \\
0.030\end{array}$ \\
\hline 4 & $\begin{array}{r}2 \\
3 \\
12\end{array}$ & $\begin{array}{r}63 \\
315 \\
200\end{array}$ & $\begin{array}{l}4.3 \\
3.6 \\
7.5\end{array}$ & $\begin{array}{l}0.068 \\
0.012 \\
0.037\end{array}$ \\
\hline 5 & $\begin{array}{r}5 \\
6 \\
7 \\
8 \\
9 \\
13\end{array}$ & $\begin{array}{l}175 \\
185 \\
215 \\
190 \\
335 \\
280\end{array}$ & $\begin{array}{l}7.1 \\
7.4 \\
6.1 \\
6.5 \\
9.2 \\
6.5\end{array}$ & $\begin{array}{l}0.041 \\
0.039 \\
0.028 \\
0.034 \\
0.027 \\
0.023\end{array}$ \\
\hline 7 & $\begin{array}{l}5 \\
6\end{array}$ & $\begin{array}{l}300 \\
240\end{array}$ & $\begin{array}{l}8.4 \\
7.8\end{array}$ & $\begin{array}{l}0.028 \\
0.033\end{array}$ \\
\hline 24 & $\begin{array}{r}4 \\
6 \\
7 \\
12 \\
16 \\
17 \\
18\end{array}$ & $\begin{array}{r}1,480 \\
905 \\
870 \\
610 \\
940 \\
1,610 \\
715\end{array}$ & $\begin{array}{r}12.0 \\
9.4 \\
11.0 \\
11.0 \\
6.7 \\
13.0 \\
4.1\end{array}$ & $\begin{array}{l}0.008 \\
0.010 \\
0.013 \\
0.018 \\
0.007 \\
0.008 \\
0.006\end{array}$ \\
\hline
\end{tabular}

* Specific activities were obtained by dividing the per cent of injected $P^{*}$ per $100 \mathrm{ml}$. plasma, red cells and urine, by the mg. per cent of phosphorus in each fraction. The use of the percentage of added $P^{*}$ rather than the number of counts as the basis of calculation permitted direct comparison of the different experiments despite variation in the actual amount of $P^{x}$ added. 
TABLE II

Urinary excretion and turnover of phosphorus

\begin{tabular}{|c|c|c|c|c|c|}
\hline Subject & $\begin{array}{c}\text { Rate of } \\
\text { Paz } \\
\text { excretion } \\
\text { Per cent } \\
\text { body } P_{n} \\
\text { per min. }\end{array}$ & $\begin{array}{c}\text { Total Pa } \\
\text { excreted } \\
\text { in } 7 \text { hours } \\
\text { after injection } \\
\text { Per cent } \\
\text { injected } \\
\text { dose }\end{array}$ & $\begin{array}{c}\begin{array}{c}\text { Rate of } \\
\text { phosphorus } \\
\text { excretion } \\
\text { (E) }\end{array} \\
\text { mg. per min. }\end{array}$ & $\begin{array}{l}\text { Size of } \\
\text { body } \\
\text { pool } \\
\text { (P) } \\
\text { mg. }\end{array}$ & $\begin{array}{l}\text { Rate at which } \\
\text { phosphorus } \\
\text { leaves pool } \\
\text { (S) }\end{array}$ \\
\hline $\begin{array}{l}1 \\
2 \\
3 \\
4 \\
5 \\
6\end{array}$ & $\begin{array}{l}0.78 \\
0.78 \\
0.79 \\
0.76 \\
0.77 \\
0.77\end{array}$ & $\begin{array}{r}10.0 \\
7.0 \\
8.0 \\
7.5 \\
7.5 \\
5.6\end{array}$ & $\begin{array}{l}1.1 \\
0.6 \\
1.0 \\
0.6 \\
0.6 \\
1.3\end{array}$ & $\begin{array}{l}1,400 \\
1,100 \\
1,400 \\
1,050 \\
1,050 \\
3,400^{*}\end{array}$ & $\begin{array}{r}10.0 \\
8.0 \\
10.2 \\
7.4 \\
7.4 \\
24.5^{*}\end{array}$ \\
\hline Avg. & 0.78 & 7.5 & 0.9 & 1,200 & 8.6 \\
\hline
\end{tabular}

* Not included in average.

movement of $\mathrm{P}^{32}$ into this fraction. The possibility exists, however, that a very slow shift of $\mathrm{P}^{32}$ into the acid soluble organic phase does take place.

Observations were made regarding the possible effects of glucose and insulin on the distribution of $\mathrm{P}^{32}$. With regard to glucose, we have data on two subjects, and in these, there was no apparent effect on $\mathrm{P}^{32}$ distribution as compared with normals (Tables IV and V). Of the three subjects receiving insulin, on whom we have detailed data, two showed no differences in $\mathrm{P}^{32}$ distribution compared to normal, while in the third, there was a slight additional shift into the acid insoluble organic phase. A pre-insulin level of 6 per cent of the total $\mathrm{P}^{32}$ increased to 16 per cent in this fraction two hours after insulin administration. The blood sugar curve was no different in this subject from those in the other two subjects nor was the curve of inorganic or total $\mathrm{P}^{32}$ concentrations different (Table V).

\section{Distribution of injected $\mathrm{P}^{32}$ in the various red cell phosphorus fractions}

Data are available in four subjects regarding partition of phosphorus fractions in red cells (Table VI). In each instance the major portion of the $\mathrm{P}^{32}$ was initially present in the inorganic fraction. At the peak uptake, about 85 per cent of the total $\mathrm{P}^{32}$ was present as inorganic phosphorus, a figure which corresponds closely with in vitro data previously obtained (12). This would seem definitely to establish the existence of inorganic

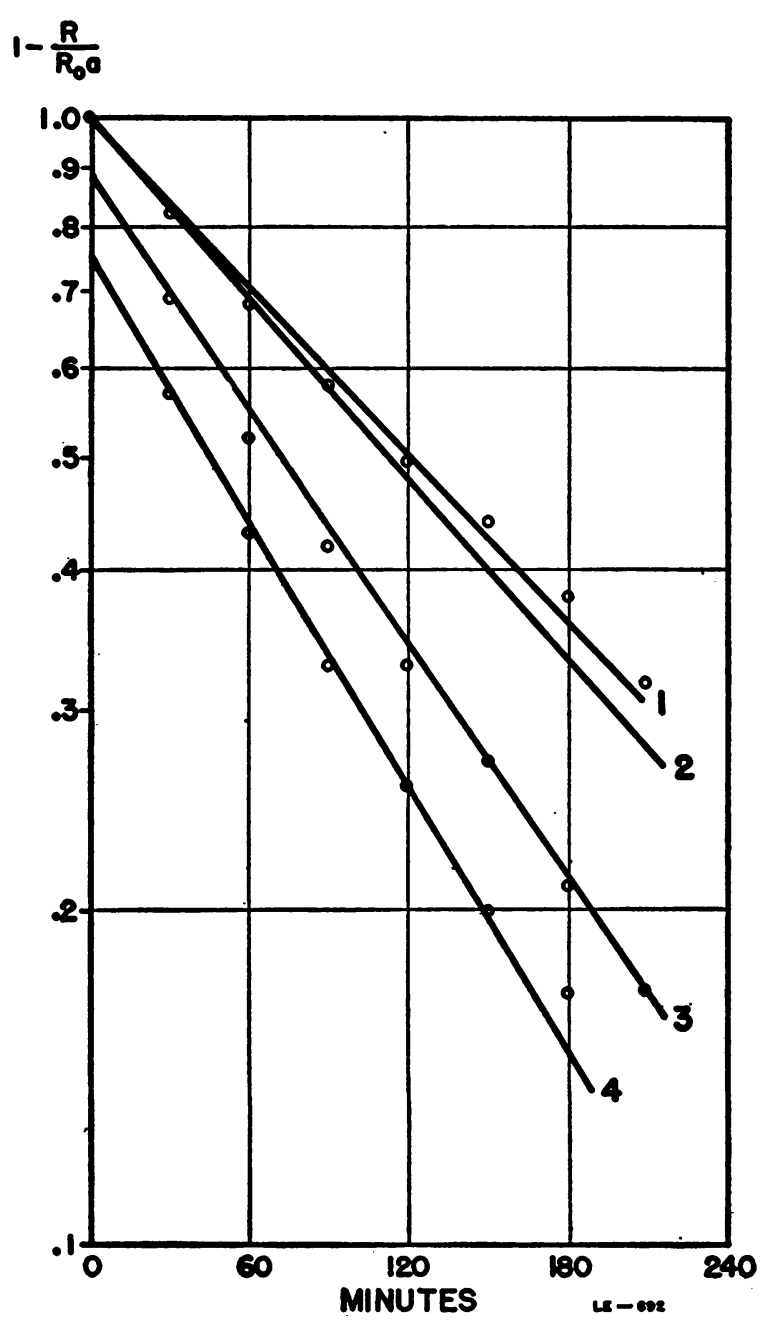

Fig. 6. Semi-logarithuic Plot of Data of Figure 5 from Which Rate of $P^{2}$ Excretion is Calculated 
S. M. Levenson, M. A. ADAMS, H. ROSEN, AND F. H. L. TAYloR

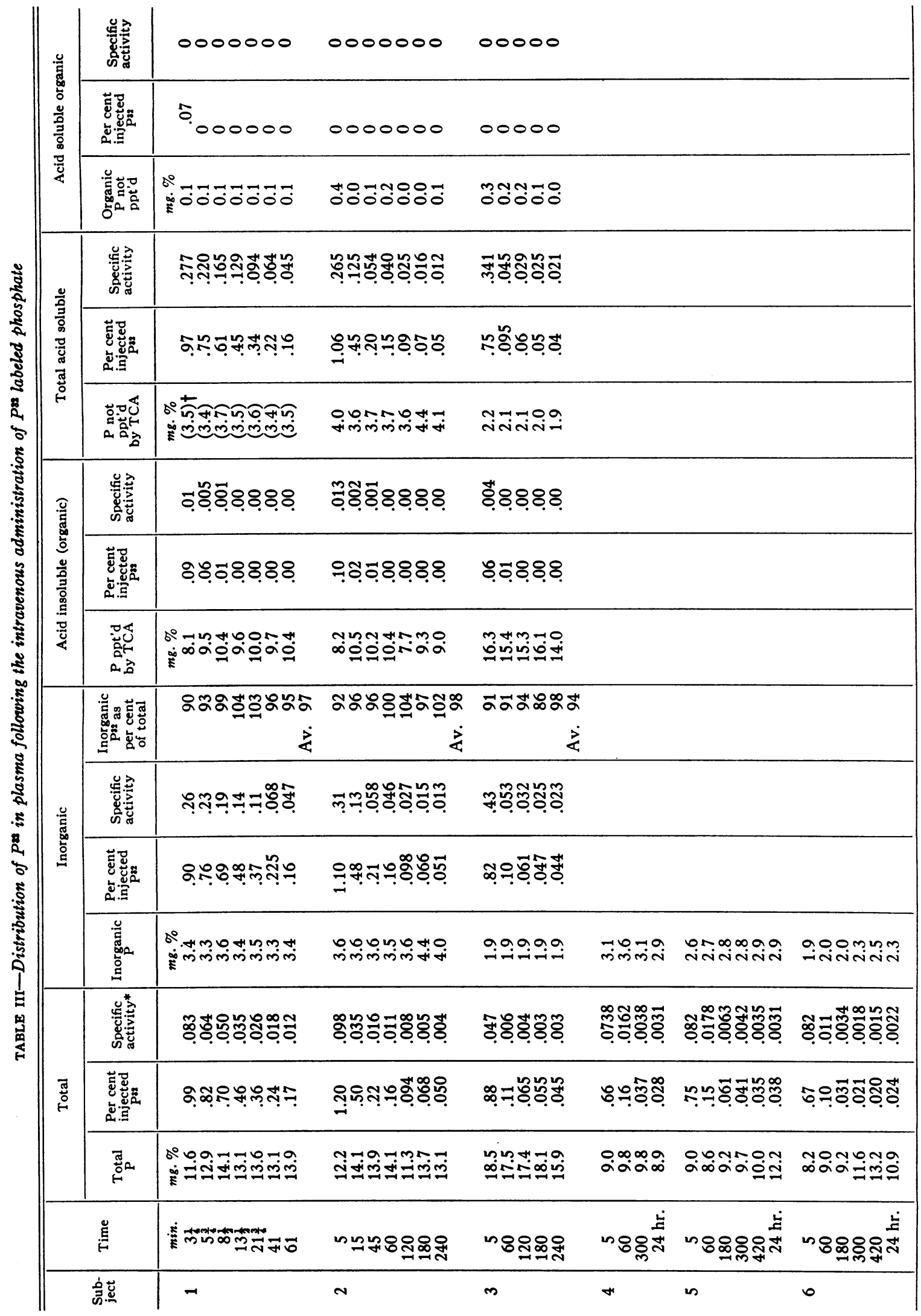




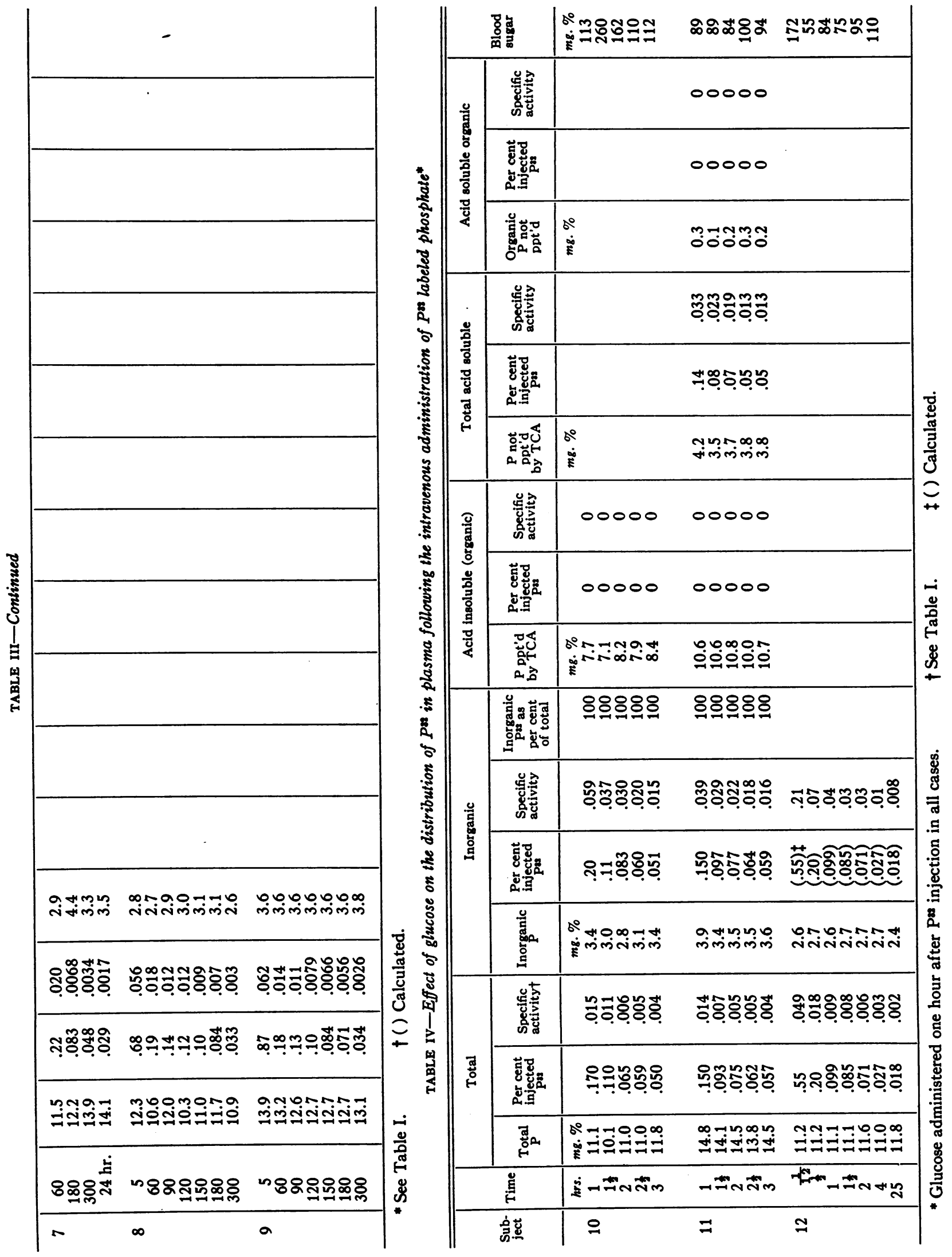


S. M. LEVENSON, M. A. ADAMS, H. ROSEN, AND F. H. L. TAYLOR

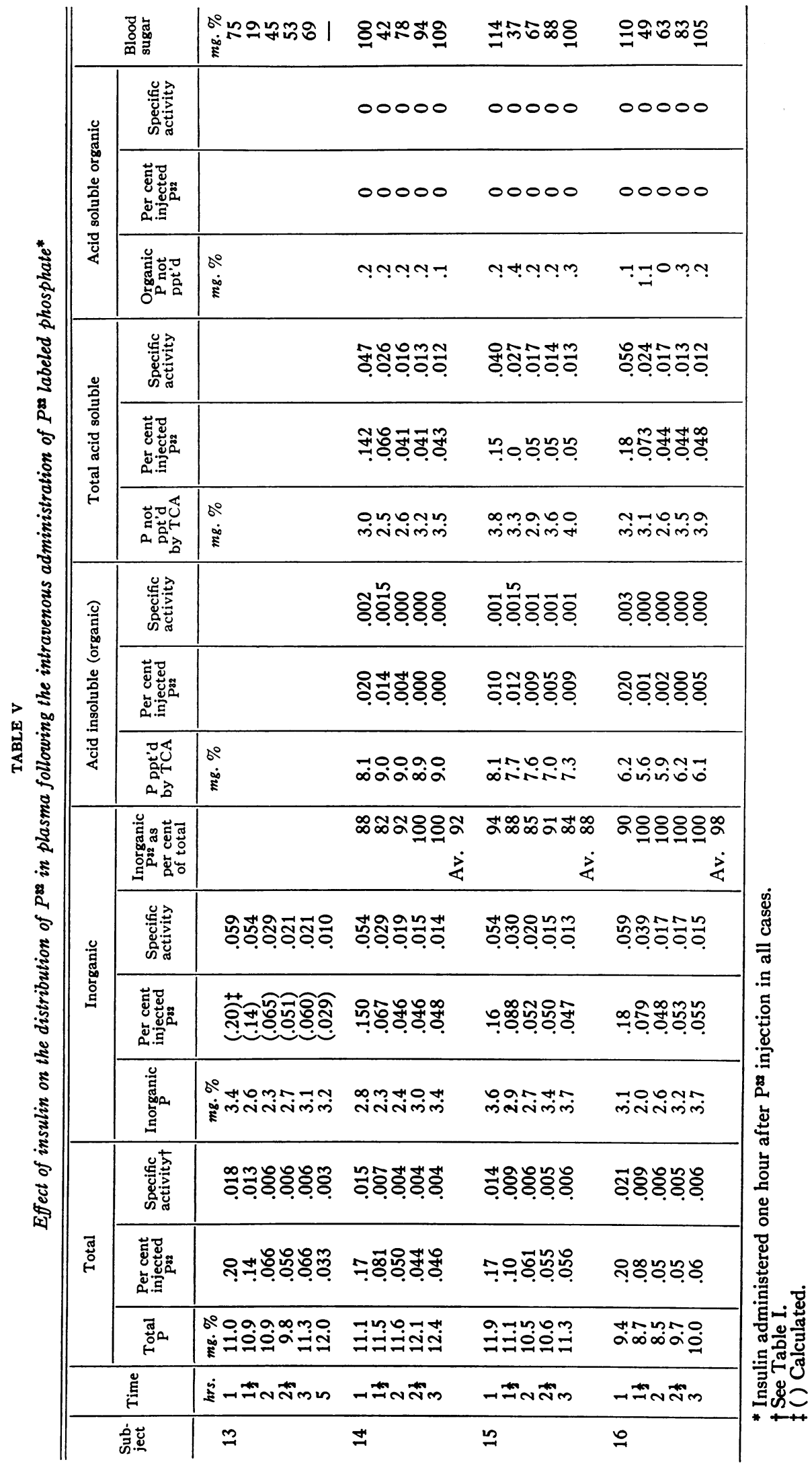




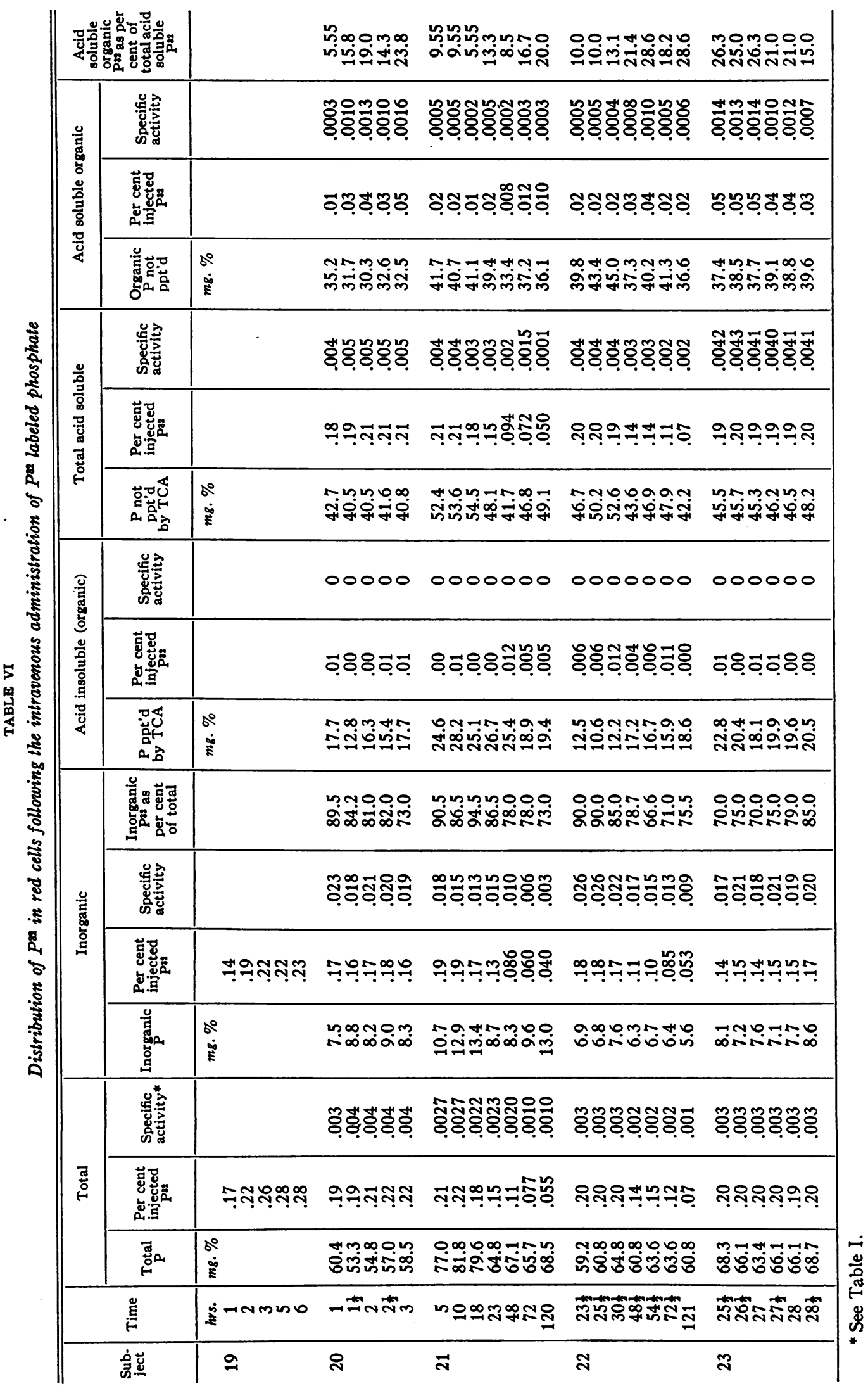


TABLE VII

Distribution of $P^{2}$ between plasma and red blood cells Specific activities* Inorganic fractions

\begin{tabular}{lcc}
\hline \hline & Plasma & $\begin{array}{c}\text { Red blood } \\
\text { cells }\end{array}$ \\
\hline $\begin{array}{l}\text { In vitro, after } 4 \text { hrs. } \\
\text { incubation at } 37^{\circ} \mathrm{C} .\end{array}$ & 14 & 13 \\
$\begin{array}{l}\text { In vivo, 5 hrs. after } \\
\text { I.V. injection }\end{array}$ & 0.019 & 0.018 \\
\hline
\end{tabular}

* See Table I.

phosphorus in human erythrocytes. What $\mathrm{P}^{32}$ is present as organic is in the acid soluble fraction.

It may be seen in Table VII that specific activities in the inorganic fractions of plasma and red cells are identical at equilibrium. This steady state has occurred both in vivo and in vitro by four to five hours. The in vitro experiments were carried out at $37^{\circ} \mathrm{C}$. In vivo, there is a gradual shift of $\mathrm{P}^{32}$ from the inorganic to the organic phase in the red cells, such that at five hours, 91 per cent of the total $\mathrm{P}^{32}$ is in the inorganic, while at 120 hours, this percentage has decreased to 71 , and the organic has risen concomitantly from 9 per cent to 24 per cent (Table VIII). All of the $\mathrm{P}^{32}$ present in the organic fraction was present in the acid soluble phase five hours after injection. In the next few days, some appeared in the acid insoluble organic phase, but the major part still was found in the acid soluble fraction.

\section{SUM MARY}

1. The distribution of radiophosphorus has been studied in various plasma, red cell, and urine fractions of normal young men following the rapid intravenous administration of 100 to 200 microcuries of $\mathrm{P}^{32}$ as $\mathrm{Na}_{2} \mathrm{HP}^{32} \mathrm{O}_{4}$. The subjects were on normal intakes prior to study. Observations were made after a 12 hour fast.

TABLE VIII

Per cent $P^{\infty}$ in various red blood cell phosphorus fractions

\begin{tabular}{ccccc}
\hline $\begin{array}{c}\text { Time (hrs.) } \\
\text { after I.V. } \\
\text { injection }\end{array}$ & $\begin{array}{c}\text { Inorganic } \\
\text { P }\end{array}$ & $\begin{array}{c}\text { Total } \\
\text { acid } \\
\text { soluble P }\end{array}$ & $\begin{array}{c}\text { Acid } \\
\text { soluble } \\
\text { organic P }\end{array}$ & $\begin{array}{c}\text { Acid } \\
\text { insoluble } \\
\text { organic P }\end{array}$ \\
\hline 5 & 91 & 100 & 9 & 0 \\
24 & 83 & 98 & 15 & 2 \\
48 & 79 & 93 & 14 & 7 \\
72 & 76 & 92 & 16 & 8 \\
120 & 71 & 95 & 24 & 5 \\
\hline
\end{tabular}

2. Most of the labeled phosphate leaves the blood within a few minutes after injection, indicating a very rapid transcapillary movement of phosphate.

3. Following this initial rapid decrease in plasma radioactivity its disappearance slows. This may represent entrance of phosphate into cells. Mathematical analysis of this transfer shows it to be of a double exponential nature. The double exponential takes the form:

$$
P=0.85 e^{-0.08 t}+0.27 e^{-0.01 t}+0.03,
$$

where $\mathrm{P}=$ per cent injected $\mathrm{P}^{32}$ per $100 \mathrm{ml}$. plasma found $t$ minutes after injection. The rate constants for the two processes are $38 \times 10^{-3}$ per min. and $7.9 \times 10^{-3}$ per min., respectively.

4. The uptake of $\mathrm{P}^{32}$ by the red cells in vivo was found to be represented by the equation:

$$
\mathrm{Q}=0.07\left(1-\mathrm{e}^{-0.30 t}\right)+0.13\left(1-\mathrm{e}^{-0.02 t}\right),
$$

where $Q=$ per cent injected $P^{32}$ per $100 \mathrm{ml}$. red cells found $t$ minutes after injection.

5. Glucose ( $25 \mathrm{gm}$.), administered intravenously one hour after injection of $\mathrm{Na}_{2} \mathrm{HP}^{32} \mathrm{O}_{4}$, accelerates the movement of $\mathrm{P}^{32}$ out of the plasma by a factor of 3, while intravenous insulin ( 0.1 unit per $\mathrm{Kg}$. body weight) accelerates it by a factor of 4 .

6. Excretion of $\mathrm{P}^{32}$ in the urine during the period one to seven hours after injection was shown to follow the process:

$$
\mathrm{R}=\mathrm{R}_{0} \mathrm{a}\left(1-\mathrm{e}^{-\mathrm{bt}}\right),
$$

where $R=$ per cent injected $P^{32}$ found in urine at $t$ minutes after injection and $a$ and $b$ are constants. The excretion of $\mathrm{P}^{32}$ was 0.8 per cent per min. of the injected $\mathrm{P}^{32}$.

7. From the above data and measurement of urinary phosphorus as such, certain average body "constants" were calculated. These are the rapidly exchangeable body "phosphorus pool" (about 1.2 gm.) and the rate at which phosphorus leaves this pool (about $8.5 \mathrm{mg}$. per min.). These data suggest that the rapidly exchangeable body phosphorus turns over approximately 10 times per day under the conditions of this study.

8. Over a four hour period following the injection of labeled phosphate approximately 95 per cent of the $\mathrm{P}^{32}$ is in the inorganic phosphorus fraction. Almost all the remaining $\mathrm{P}^{32}$ is in the acid insoluble organic fraction. No definite changes 
were found in the $\mathrm{P}^{32}$ distribution in the plasma phosphate fractions as a result of glucose or insulin administration.

9. The distribution of $P^{32}$ was also studied in various red cell phosphorus fractions. At peak uptake (about five to seven hours after injection) about 85 per cent was found in the inorganic phosphorus fraction. The specific activities of $\mathrm{P}^{\mathbf{3 2}}$ in the inorganic fractions of plasma and red cells are identical at this time. There is a gradual shift of $\mathrm{P}^{32}$ from the inorganic to the organic fraction so that at 120 hours after injection about 30 per cent of the $\mathrm{P}^{32}$ is present as organic phosphorus, chiefly as acid soluble compounds.

\section{REFERENCES}

1. Fiske, C. H., and Subbarow, Y., Phosphocreatine. J. Biol. Chem., 1929, 81, 629.

2. Adams, M. A., Levenson, S. M., Fluharty, R. G., and Taylor, F. H. L., Methods for the determinations of radioactive phosphorus $\left(\mathrm{P}^{*}\right)$ in body fluids. $\mathrm{J}$. Lab. \& Clin. Med., 1949, 34, 1301.

3. Gourley, D. R. H., and Gemmill, C. L., The effect of temperature upon the uptake of radioactive phosphate by human erythrocytes in vitro. J. Cell. \& Comp. Physiol., 1950, 35, 341.

4. Erf, L. A., and Lawrence, J. H., Clinical studies with the aid of radioactive phosphorus. I. The absorption and distribution of radio-phosphorus in the blood and its excretion by normal individuals and patients with leukemia. J. Clin. Invest., 1941, 20, 567.

5. Cardozo, R. H., and Edelman, I. S., The volume of distribution of sodium thiosulfate as a measure of the extracellular fluid space. J. Clin. Invest., 1952, $31,280$.

6. Pappenheimer, J. R., Renkin, E. M., and Borrero, L. M., Filtration, diffusion and molecular sieving through peripheral capillary membranes. A contribution to the pore theory of capillary permeability. Am. J. Physiol., 1951, 167, 13.

7. Kleiber, M., Smith, A. H., and Ralston, N. P., Mixing rate of phosphate between plasma and interstitial body fluid of cows. J. Gen. Physiol., 1950, 33, 525.

8. Walker, W. G., and Wilde, W. S., Kinetics of radiopotassium in the circulation. Amer. J. Physiol., 1952, 170, 401.

9. Solomon, A. K., Equations for tracer experiments. J. Clin. Invest., 1949, 28, 1297.

10. Sprinson, D. B., and Rittenberg, D., The rate of interaction of the amino acids of the diet with the tissue proteins. J. Biol. Chem., 1949, 180, 715.

11. Widdowson, E. M., McCance, R. A., and Spray, C. M., The chemical composition of the human body. Clin. Sc., 1951, 10, 113.

12. Taylor, F. H. L., Levenson, S. M., and Adams, M. A., Studies of phosphorus metabolism in man: II. A study of the permeability of the human erythrocyte to inorganic phosphate in vitro by the use of radioactive phosphate $\left(\mathrm{P}^{\mathrm{x}}\right)$. Blood, 1948, 3, 1472. 